\title{
О ПРЕЗИМЕНУ ПАЛАВЕСТРА И СЛИЧНИМ ПРЕЗИМЕНИМА
}

Рад разматра етимологију српског презимена Палавестра и њему сличних српских презимена, нпр. Палонга, Паловртић. Њихов први део, Пала-/Пало-, етимологише се од далматороманске (а - можда одатле - и балканороманске) речи *pala/*pal-o- „мач”. Разматра се и делимична могућност опсценог значења ове речи у неким од поменутих презимена, при чему се даје предлог етимологије неколико српских назива за даље мушке претке: парђипан, (?) *курђуп, курлебало, куриула, сукуребало, сукурдов са ж. сукурдача, (?) *сурдепач, *ожмикур, курајбер, можда чак и бели орао.

Кључне речи: Палавестра, парђипан, (?) *курђуп, курлебало, курцула, сукуребало, сукурдов, (?) *сурдепач, *ожмикур, курајбер, бели орао.

Породица Палавестра јавља се у Херцеговини на три места, у граду Мостару, селу Ходбини у Бишћу и селу Гнојници код Мостара. У Ходбину су се доселили из Мостара, а у Гнојницу из Ходбине. Јевто Дедијер бележи како „нагађају да су старином из Грахова”. Православци су и у Мостару славе Никољдан, а ван Мостара Ђурђевдан. Стара су и позната мостарска српска породица, из које потиче наш чувени публициста и књижевник Јован Палавестра (1893, Мостар - 1959, Сарајево) (Милићевић, 2005: 548; Дедијер, 2004: 283, 291). Најстарији сачувани надгробни споменик мостарских Палавестри јесте споменик извесног Симата² Палавестре, из 1825. г. на Пашиновачком гробљу у Мостару, где је уклесан епитаф на славјаносербском: „† Исус Назарећанин, ияар јудејски, побеђује! Мјесто које се зове коштурница рај постаде. ${ }^{3}$ Овде почива слуга Божији Симат Палавестра, нека му је вјечнаја радост и блажен покој! Преставио се 1825. г.” (Станић, 1994: 162, 166, 167, 170) (в. сл. 1):

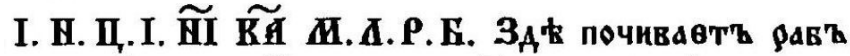

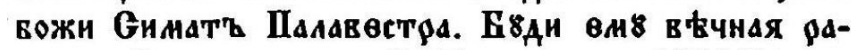 АОСт' і БААЖөни ПОкой. Прөставн сө 1825.}

Сл. 1. Епитаф Симата Палавестре из 1825. г. (Станић, 1994: 166)

\footnotetext{
${ }^{1}$ sapphousatthis@gmail.com

${ }^{2}$ Српско мушко име (одмиља) Симат отприлике је исто што и име (одмиља) Симан, са̀мо $\mathrm{c}$ другачијим суфиксом (-am : - $а н)$, а оба су изведена - преко имена (одмиља) Сима - од имена Симеун/Симеон/Симијан/Сими(ј)он/Симон/Симун (Грковић, 1977: 179).

${ }^{3}$ Рус.слов. (млађе црк.слов.) Мьсто Лобпов рай быстъ.
} 
Поменуто српско презиме Палавестра се чак и лаичком оку сместа разлаже на два дела, Пала- и -вестра, при чему се други део -вестра сместа препознаје како има везе са италијанским vostro/vostra, тј. латинским vester/ vestra/vestrum, „ваш”, те да је ово пореклом латинско, односно романско презиме.

Међутим, известан проблем настаје када се у нашој стручној литератури погледа порекло првог дела овог презимена, Пала-. Клаићев речник страних ријечи наводи nàлa, турцизам од турског pala, у значењу „дугачак бојни нож, сабља” (Клаић, 1966: 910). Речник Матице српске (u Матице хрватске) исто наводи: па̀ла/па̀ла, турцизам, у значењу „кратак широк мач који најчешће има држак и корице оковане сребром”, с примерима убојна пала и пала звизне (РМС-МХ 4, 1971: 308). Речник CAHУ такође каже: nàлa/nà̀a, турцизам од турског pala, у значењу ,(1) кратко широко сечиво, сабља која обично има држак и корице оковане сребром и носи се за појасом; (2) врста ножа за клање домаћих животиња", с примерима пала посјеклица, посјећи палом, повадити пале, оштра пала, пала звизне, а наводи се и синоним палашина (РСАНУ ХІХ, 2014: 193). Исто тако и у раду Марије Ђинђић (као коауторке) о архаичним турцизмима у савременом српском књижевном језику и њиховом статусу у савременом турском књижевном језику: ,[Sirp] pala ([< Türk.] pala)” (Јалап-Ђинђић, 2016: 276). У Скоковом Етимологијском рјечнику пак вели се прецизније да je пала ,veliki nož što se za pojasom nosi”, српски турцизам од турског pala „mač, krummer Säbel”, из турске војничке терминологије, те да је то, шире, балкански турцизам ког сведоче и румунско pala, бугарско naлa ,bradva, kojom se odsijeca glava čovjeku", ш(ћ)иптарско pallë, те (ново)грчко то́ $\lambda \alpha$. А из мађарског турцизма, где је додат и суфикс -os, pallos, долази наша реч палош, с придевом палошасm „dvosječan” и аугментативом палошина, затим румунско paloş, као и облик са [-aš], [palaš] у српском, словачком, чешком, пољском, горњолужичкосрпском и немачком, све у значењу „тас̌”. Такође, на бугарски турцизам пала додат је и суфикс -еш, одакле реч палешник „,[оштри] dio na ralu” (ЕРХCJ 2, 1972: 589). А Речник Ивековић-Броз повезује етимолошки па̀ла са немачким Pallasch, и даје примере пала позлаћена, пала окована и пала латинкиња (Ивековић-Броз РХJ, 1901 II: 4, 5).

Даље етимологишући, Шкаљићев рјечник туризиама наводи да је па̀ла „(1) sablja, odnosno kratki široki mač u koga su obično držak i korice okovane srebrom; (2) štap kojim se igra klisa", с примерима златна пала и пала окована, те да је то турцизам од турског pala, што је реч грчког порекла, наиме, османски турски лексикографи „М[ehmed] Salahi i [Ahmed Vefik-paša, u] Lehdže-i-Osmani, navode da je riječ porijeklom n[ovo]grč[ka], dok Barbier de Meymard dovodi je u vezu sa grč[kim] pálē, pála" (Шкаљић, 1989: 53, 56, 508).

Наведена Шкаљићева етимологија указује на јасну могућност да је у нашем приморском далматороманском - у којем је било директних грецизама 
- постојао и грецизам *pala, у значењу „мач”, односно, да је средњогрчко $\pi \alpha \dot{\lambda} \alpha$,мач” дало далматороманску реч *pala, „истог значења”. Но, постоји такође друга могућност, да је ова реч у грчки дошла из романитета, где је гласила исто, *pala, а постала је преласком у $а$-деклинацију латинске речи средњега рода pālum, $-i$ n., споредног облика ре̂чи pālus, -i m., која је поред основних значења „колац, ступ, стуб, мотка” - имала, у облику palus primus или palusprimus, и значење ,дрвени гладијаторски мач који носе секутори, чији се вођа зове стога (исто) primus palus”, па чак и опсцено значење „бу а (мушка), 'мачета' (у гаћама)" (Луис-Шорт, 1891: 1295). А на овај правац 'шетања' реєчи указивало би то што у грчком имамо из латинског преузету ову реч, у облику мушкога рода, $\pi \tilde{\alpha} о \varsigma$, у значењу „мотка, колац” (Софоклис, 1900: 833).

Наведену реч *pala би - којег год да је порекла - у далматороманском (a - можда одатле - и у балканороманском), по нашем мишљењу сведочило неколико од ње начињених српских презимена:

1) Далм. и балк.ром. - лат. (учено) *pala vestra 4 „Ваш мач”, у смислу инвеституре племића/витеза, где се каже: „Ваш мач, сире!” или пак међусобнога обраћања племића̂/витезова Ваш мач или сл. > през., срасло, *Palavestra $>$ през. Палавестра у Мостару, Ходбини и Гнојници у Херцеговини, као и Палавестра или (српском асимилацијом $a: e>a$ : а) Палавастра у Никшићу у ЦГ (Миљанићи, 2002: 338). Речник САНУ наводи и облик (с додатим -uћ на облик на -a) Палавестрић у Колубари и(ли $)^{5}$ Подгорини у Србији, као и на NN месту, а по сведочанству академика (САНУ) Милосава Тешића (PCAHУ XIX, 2014: LXXVII, CII, 194). Такође, по предању у породици познатог српског фрулаша Борислава-Боре Дугића, из села Ђурђева код Раче (Крагујевачке), Дугићи су ,poreklom... iz plemena Palavestra iz Crne Gore, sa Skadarskog jezera” (Антонијевић, 2008).

2) Вероватно балк.ром. *pala longa, можда и срасло у једну реч, са спојним вокалом -o- (наместо -a), ${ }^{6}$ *pal-o-longa „дуги мач”, у смислу дугог дворучњака или сл., односно у смислу у ком и српски пример палошина или палашина (в. горе) > през., срасло, *Palalonga/*Pal-olonga > през. ((балкано)романском или српском хаплологијом la/lo : $l o>\varnothing:$ : или ла/ло : ло > Ø : ло) Палонга, односно (с додатим -uћ на облик на -а) Палонгић, у Бару у ЦГ (Миљанићи, 2002: 339, 340).

\footnotetext{
${ }^{4}$ Да балканоромански ближе приморју, те далматороманском, може да остави (нередуковано и неапокопирано) завршно $-a$, уп. доле балк.ром. *Santamarja ${ }^{*}$ Sant-o-marja и *Luntaduklja/*Lunt-o-duklja.

${ }^{5}$ Формулација $A$ и(ли) Б значи ,паралелно $A$ и Б и $A$ или $D^{\prime \prime}$. И даље.

${ }^{6}$ УП. ојк. ром. *Santamarya / балк.ром. *Santamarja > балк.ром. *Sant-o-marja > срп. Сутоморе, те (?) ојк. ром. *Luntaduklya / балк.ром. *Luntaduklja > балк.ром. *Lunt-o-duklja > Lontoduklja

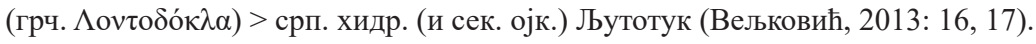


3) Можда далм.ром. *pala dura „чврсти или јак, силан, несалом(љ)ив(и) мач", у смислу да је нескршив, силан или сл. > през., срасло, *Paladura $>$ през. (с додатим - $и$ на облик на - $a$, и метатезом) Паладруић, односно ((?) уклањањем хијата $y u>u$, или пак аналогијом према корену $\partial(e) p$-) Паладрић, у Вијенцу код Пљеваља у ЦГ (Миљанићи, 2002: 338).

4) Можда балк.ром. *pala okuta (< лат. acutus/-a/-um) „оштри мач”, у смислу у ком и српски пример оштра пала (в. горе) > през., срасло, *Palaokuta $>$ през. (српском контракцијом $a o>\hat{o}$, те (?) скраћивањем - $a$ према речи кут, Кути у топонимији) Палокут у Бару у ЦГ (Миљанићи, 2002: 339).

5) Можда далм.ром. * pala verte (< лат. viridis, -e),,[зелен и свеж као биље $\rightarrow$ ] крепки мач", у смислу за бој вазда крепког/живог, јуначког/јуначног мача или сл. > през., срасло, *Palaverte > през. Палаврт у Досуђу или Заграђу код Гусиња у ЦГ, односно (с додатим -uћ на сугласник) Палавртић у Досуђу и Заграђу код Гусиња у ЦГ, пре и у Кучима у ЦГ, одакле у Горњој Ржаници у ЦГ као и у Метохији (Миљанићи, 2002: 338). Речник $C A H У$ наводи и облик презимена Палаврта (са, онда, нашим - $a$ наместо романског -e) $)^{7}$, односно (с додатим -uћ на облик на -а) Палавртић у Маћедонији / Егејској Македонији и(ли) јужној (Старој) Србији ${ }^{8}$ (РСАНУ XIX, 2014: CIX, 194).

5а) Исто као и под 5), али вероватно, и срасло са спојним вокалом -о(наместо -a), *pal-o-verte > през., срасло, *Paloverte $>$ през. (с додатим -uћ на сугласник, -m) Паловртић (,(од) Паловртића̂”) код Плава у ЦГ (Миљанићи, 2002: 339).

6) Под знаком питања далм.ром.-итал.лат. *pala ori (< лат. aurum, ген. auri) „златни/злаћани мач или мач који се злати”, у смислу у коме и српски примери златна пала и пала позлаћена (в. горе) > през., срасло, *Palaori > през. (с додатим -ић на самогласничко -u) Палаорић у Потподима у Бјелопавлићима у ЦГ (Миљанићи, 2002: 339).

\footnotetext{
${ }^{7}$ Уп. у романитету lume > срп. лума (уп. ЕРХCЈ 2, 1972: 330; уп. Шкаљић, 1966: 433, 436 (нег. налаз); в. и Драшковић, 1994: 17, 22). УП. такође тур. kâse > срп. турц. ћaca, тур. derece > срп. турц. дереиа, као и тур. köfte > срп. турц. ћyфme (ген. -ета) и ћyфma (ЕРХСЈ 1, 1971: 350, 362, 392; Шкаљић, 1966: 184, 198, 212; PMC-MX 6, 1976: 372). Петар Скок објашњава да је ту ,dočetno $-e . .$. bi[1]o identificiran[o] s našim -e u pluralu (f.), i odatle [je] stvoren novi sing. na $-a "$ (EPXCJ 1, 1971: 350).

${ }^{8}$ Овде користим традиционалне називе Маћедонија / Егејска Македонија и јужна (Стара) Србија. Историјскогеографски, реч је о јужној (Старој) Србији до југа данашње републике Северне Македоније, до линије: јужно од Дебра и Кичева - изнад Крушева - северно од Прилепа - север Мариова - отприлике Демир-Капија - отприлике Малешевске планине, одакле започиње, ка југу, Маћедонија / Егејска Македонија. Док, тзв. Вардарска Македонија јесте, суштински, један политички термин који нема упоришта у историјској географији нити, уопште, географији (Иванић 1911). За формулацију А и(ли) Б в. горе.
} 
6а) Исто као и под 6), али далм.ром.-лат. *pala avri, можебити и контраховано у * palāvri „истог значења" > през., срасло/контраховано, *Palāvri > през. (према речи палавра, директно или индиректно) Палавра у Пљевљима у ЦГ (Миљанићи, 2002: 338).

7) Под знаком питања балк.ром. *pala mlaur „мач са змајевом главом на јабуци, (?) мач попут змиј(етин/урин)е или (?) змијолик(и)”, можда и срасло у * palamlaur, а у оном смислу у ком и румунско bălaur ,змај (велика змија)", као и српски (с убаченим - $a$-, те додатим - $a$ вероватно према змија) балаура м. *,змија, ђаво”, и (од блавор, одн. балавор, са додатим - $а$ према сабљ $а$ те асимилацијом $o: a>a: a)$ у нар. поез. покр. балавара 〈! крива , ${ }^{*}$ сабља попут змије или *змијугава, врста криве сабље" (ЕРХCЈ 1, 1971: 169, 170; уп. ЕРС 2, 2008: 117; РСАНУ I, 1959 : 265, 268) > през., срасло, *Palamlaur > през. ((балкано)романским развојем $a u>u,{ }^{9}$ те вероватно српском дисимилацијом $\left.л: л>л: \varnothing\right)$ Паламур у месту 'Вељи Острос' (Острос) 〈!〉 уз Скадарско језеро, у Крајини у ЦГ (в. и горе) (Миљанићи, 2002: 339).

8) Под знаком питања далм.ром.-итал. *pala dretta (< лат. directus/a/-um) ,уперени/наперени мач”, у смислу исуканог мача или сл. > през., срасло, *Paladretta > през. ((далмато)романском синкопом - $a$-, (далмато)романском или српском обрнутом дисимилацијом од $l: r>\varnothing$ $: r$ или $л: p>\varnothing: p$ зарад очувања pal-/naл-, те према имену Деда/Дедо/ Дед- у антропонимији) Палдеда у Дубровнику (в. Михајловић, 2002: 727 (двоосн. реч)).

За крај, као аналогију и потврду, а и занимљивост, наводимо неке примере значењски истих или сличних употреби уз речи са значењем „мач” или уопште „оружје” или у вези с оружјем и војницима, у латинитету и у романитету. Луис-Шортов латински речник доноси примере:

- ferrum tres pedes longum, дуги мач, копље (и свако оружје), у тексту дуг(о) три римске стопе (око $90 \mathrm{~cm})$ ",

- durum in armis genus, „племе јако на оружју или силно кад се ухвати оружја",

- gladius acutus „наоштрен/оштар мач”,

- milites aurati „отпр. војници који се злате од/због злаћаних штитова",

- $\quad$ (уп.) draco „војна застава римске кохорте, са представом змаја при врху копља",

- dirigere tela „на непријатеља уперити/наперити копља, стреле или сва оштра оружја (укључујући и мач)"

\footnotetext{
${ }_{9}^{9}$ Уп. лат. pauperes $>$ балк.ром. *Pauper- $>$ *Puper- > срп. Пипери (Лома, 1993/95: 129).
} 
(Луис-Шорт, 1891:26, 208, 584, 612, 621, 1076). Док, Речниксредњофраниуског (и старофраниуског) Грејма-Кин доноси стари француски пример lance verte „коњаник-копљоноша (за бој вазда) жив, и јуначан, букв. копље (за бој вазда) живо, и јуначко [синегдохом, pars pro toto]" (Грејма-Кин, 2001: 377, 653). А старофранцуска Песма о Роланду даје нам исто стари француски пример, vostre espee „Ваш мач”, у једном од бој(ев)них дијалога Роланда и Оливера, који овде доносимо у целости у чувеном преводу Влада Драшковића (а где има и још за нас одговарајућих примера):

„I Oliver jezdi kroz ljuti okršaj,

u ruci drži komad drške od koplja koje je slomio;

udara jednog neznabošca, Malona,

lomi mu «! štit koji je u zlatu (= li freint, ki est ad or) i dragom kamenu,

i izbija mu oba oka iz glave,

a mozak prosipa po zemlji;

zatim ga mrtvog obara među stotine drugih.

Onda još obori Turdžisa i Esturgoca,

ali mu se drška od koplja raskomada sve do šake.

Tad Roland reče: 'Druže, šta činite?!

U takvom boju ja na toljagu i ne mislim!

Tu jedino valja gvožđe i čelik.

A gde je «! Vaš mač Altkler (= vostre espee, ki Halteclere ad num)

sa 〈! zlatnim balčakom (= d'or est li helz) i jabukom od biljura?'

- 'Nisam ga imao kad izvaditi', odgovori mu Oliver,

'jer sam morao zadavati tolike udarce!'

Kont Oliver poteže svoj dobri mač

što mu ga njegov saborac Roland spomenu,

te mu pokaza kako se njim viteški služi,

udari na jednog bezbožnika, Džustina iz Valfere,

po sredini mu raspoluti glavu,

preseče mu i telo i pleteni pancir,

pa $\measuredangle !$ dobro sedlo optočeno zlatom (= la bone sele, ki a or est gemmee),

preseče i kičmu njegovom konju,

pa ih mrtve obori preda se u livadu.

Tad reče Roland: 'Poznajem Vas, brate!

Zbog takvih nas udaraca car voli!'

Sa svih strana se razleže poklič Mondžoj!"

(Драшковић, 1987: 108-111).

На концу (а не желећи да кваримо суштаствено епски утисак), да напоменемо како - у случају да је далматороманска (и балканороманска) реч *pala пореклом од латинског pālum, -i n. - постоји и (наглашавам) делимична могућност опсценог значења ове речи у неким од горенаведених презимена. Дакле, према посведоченом латинском споредном, опсценом значењу „бу а (мушка), 'мачета' (у гаћама)" (в. горе), 
- $\quad$ да горенаведено далм.ром. (и балк.ром.) *pala longa/(?) *pal-olonga значи и „дуги отпр. пала ар (у гаћама) ${ }^{10}$,

- (?) далм.ром. *pala dura да значи и „чврсти или јак, силан, несалом(љ)ив(и) отпр. пала ар (у гаћама)",

- (?) балк.ром. *pala okuta да значи и „оштри отпр. пала ар (у гаћама)”,

- далм.ром. (?) *pala verte/*pal-o-verte да значи и „крепки отпр. пала ар (у гаћама)",

- (?) далм.ром.-итал.лат. *pala ori или (?) далм.ром.-лат. *pala avri/*palāvri да значи и „златни отпр. пала ар (у гаћама)" у смислу „толико добар/сјајан да злата вреди”,

- (?) балк.ром. *pala mlaur да значи и „отпр. палаар (у гаћама) са змајском главом, (?) отпр. пала ар (у гаћама) попут змиј(етин/урин)е или (?) змијолик(и)",

- (?) далм.ром.-итал. *pala dretta да значи и „уперени/наперени отпр. пала ар (у гаћама)”.

То би ишло подруку са неколиким латинским примерима које проналазимо у чувеној Кюизи шалаิ (Liber facetiarum) Пођа Брачолинија:

- longo sunt Priapo „dugačka im je ki a”,

- (уп.) haec (maledicta) caro „ova (prokleta) 'komadina mesa”,,

- (уп.) telum ,svoje ubojito 'koplje”,

- (уп.) virga tumentior fieret „njegova je ki a... stalno bujala”,

- (уп.) membrum suum ejus naturae, ut quum mulierem prima tantum parte cognosceret, mercatores faceret, secunda milites, tertia duces, quarta pontifices, et pretium pro qualibet personarum petebat. „njegov je [ku].[ac] takvih sposobnosti da pravi trgovce ako posao obavlja njegov prvi dio, vojnike ako drugi, vojskovođe ako treći, a pape ako četvrti. Cijena, razumije se, za svaki stepen zvanja nije ista.",

- (уп.) praeputium... asini „magareći 'glavičak””, (уп.) vir, cum semiasellus in ea re videretur „muž, u koga je bio gotovo pola magarčeva”,

- (уп.) jam enim virga erecta erat „ki a mu se bijaše već dobro nadigla” (Брачолини, 1962: 70, 71, 124-126, 230, 231, 240-243, 326, 327). Све ово и не треба да чуди јер муже(ст)в(е)ност иде подруку с мушком сексуалношћу и плодношћу, и то је одискони било тако, а у прошлости и те како отвореније и јавније него данас. Као природан пример тога, можемо навести 'опсцене' и делом пореклом шаљиве, а у ствари маскулине сексуалноплодничке етимологије (понегде су то реетимологије) неколико српских назива за даље мушке претке, ${ }^{11}$ већином новијег датума:

\footnotetext{
${ }^{10}$ Синтагма отпр. пала ар (у гаћама) јер она би обухватила и значење „бу॰а (мушка)” и „'мачета' (у гаћама)".

${ }^{11}$ На овом месту, ми се најискреније надамо да оваквом анализом нећемо никога увредити или да нам се све ово неће за зло узети, а услед тога што сматрамо да постоји макар делимична могућност да јесте овако како ми излажемо и предлажемо.
} 
- парђипан/(?) *парађипан (ж.: наврнбаба, наврибаба) „пара-, тј. *прађипан, односно *пра-ждребац коме 'она ствар' (воли да) ђипа, тј. скаче",

- (?) *курђуn (ж.: курђупа, такође и курђела) „коме *ђупа, тј. ђипа/ скаче ‡ку̀р, скочик р (од мушкарца)”, постало реетимологијом, према $ћ$ кур, од курђел, ${ }^{12}$

- курлебало/куребал/курёбало/курејбало (ж.: куребала) < *кі̀р - јѐало ,†кур који је јѐ ало (за јеање)"13 (реетимологишући, (?) од куेрало „дрвени клип или дебео прут - *јѐ ало, (?) такође и *џа̀рало по ватри, *та̀̀рило за паљење ватре, (?) исто тако и *ства̀рало, *ра̀ђало, у смислу да представља 'мушко' та̀̀рило (мушкару) и мушког претка"' или пре, реетимологишући, (?) од *курбал/*куробал/(?) *куребал ${ }^{14}$ < *курибабъ/*кур-о-бабъ „који џара по ватри у баби / бабу, је е бабу, можда и у обредном смислу, можда чак и бабу вештицу / Бабу", и то би, онда, био семантички модел за творбу осталих овденаведених назива),

- куриула (ж.: куребала) *,који има ку ащ, тј. ку чину”, постало од реетимологисаног презимена Курсула у облику презимена/(?) шпицнамета Куриула према речи ку аи, ген. куча, или можда чак од на тај начин посталог апелатива (?) *куриула м., све у значењу „који имају или који има ку ац, тј. ку чину”, и вероватно је реч о реетимологији назива куребало,

- сукурёбало/сукурбал/*скуребало (ж.: сукурдача) < *скүрр - јѐало „łскур који је јѐ ало ('за да је е')" или (?) *c-ку̀ेp - јѐ ало / *c-кŷp јѐ ало „*с-ку̀ेр/*с-куิр ${ }^{15}$ који је јѐ ало (за је ање)”,

- сукурдов/*скурд-/(?)*скурдаС(-)/(?)*скурд[]С(-) (ж.:сукурдача/*скурд-/

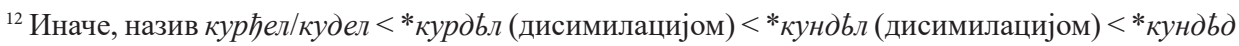
$<$ изв. слов. *кy-дбдъ ,зли деда, *злодеда, злодух, ђаво” или, пак, са нашим ун за în (?) < изв. балк.ром. *kînded $(u)<$ лат. candidus/-a/-um „бео; сед” с потоњим помер. знач. $\rightarrow$ cmap, (?) уп. бели орао (лит. в. горе).
}

${ }_{13}$ Да је овај данас опсцени (Скок каже: posvema prostački) глагол некад означавао обичну/ уобичајену сексуалноплодничку еротско-емотивну радњу којом се ствара, наставља

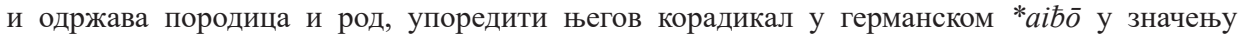
„породица, предео/област” (Покорни, 2007: 298; ЕРХСЈ 1, 1971: 765).

${ }^{14} \mathrm{У}$ речи би била извршена дисимилација (лабијала̂) $\sigma: 6>\sigma$ :л, што је обрнута дисимилација (лабијала̂) од в : $\sigma>\pi: \sigma$, у нпр. свобод $a>$ слобода (в. Белић, 1976: 143). Да овде нагласимо како на други део речи,

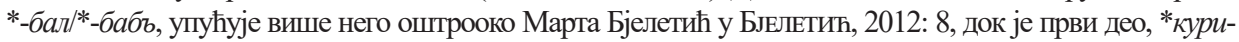
$/ *$ кyp-o- < * курити ,џарати (по ватри), је ати", предлог наше маленкости. За -о- < гл. -ити и баба >-бабупоредити: корити, он кори + коза/козе > *кор-о-коз-b , ${ }^{*}$ који кори козе, тј. који иде главом кроз зид, отпр. који пи а уз ветар" > ЛИ Корокозь, поред уобичајен(иј)е творбе корити, кори! + слава > ЛИ Кори-слав-ъ (Баженова, 2002, s. vv.; уп. Шуљгач, 2016: 191; Морошкин, 1867: 102; Лома, 2005: 25).

${ }^{15}$ Реч је о називу за претка $\ddagger c к \hat{p}$, „прадеда”, (?) такође реетимологисаном са $\ddagger$ ку̀р као његова експресивна верзија *c-ку̀р, или пак (?) реетимологисаном, према †ку̀ेр, од аскур- у аскүิрђел/ àcку̃рђел/аскурдjeл/àcку̃рдјељ или сл. (чак за̀ку̃рђел) као његова експресивна верзија *c-күิp, и то онда када се аскурђел/аскурдјел, постало < *nра-скур-дбд (?), „деда прапрадеди (6. мушки предак)”, није више повезивало са †скуিр (лит. в. горе). 
(?) * ${ }^{*}$ скурдркача, ${ }^{16}$ одакле је можебити творбом обрнутим смером начињен секундарни мушки род сукурдов!) < (?) *скуेрд к или *скуेрд к „који д。ка †скурру или (?) који д。ка *c-ку̀р/*сс-куิр”,

- (?) * сурдепач/(?) *сукурдепач (ж.: сурдепача/(?) * сукурдепача) < (?) *сукурдоје ач „који је е сукурдова”,

- ажмикур/*ожмикур (ж.: сурдепача) *,који †о̀жме̄, тј. исцеди/ оцеди ‡ку̀ेр, цѐдик р (од мушкарца)”,

- курајбер/(?) *курабер ${ }^{17}$ (ж.: бела орлииа $)<(?)$ *кура́бет *,ћку̀р (далеки) сродник”, постало укрштањем турц. кара́бет „сродство, сродништво"18 са нашим $\ddagger$ ку̀р, или пак (?) од 'укрштеног' *ку̀р кара́бет,

- можда чак и бели орао (ж.: сурдепача, а са̀мо по смислу бела орлица, која нема м. осим по смислу бели орао), под условом да је постало (?) < *белорао < *белорало < *бело орало 19 „од сперме/ семена белеће се или белога семена дајуће (мушко) 'о̀рало"'

(Бјелетић, 1994: 200; Информатор 1 (курѐбало, сукурѐбало, за̀куг рђел) [не наводи БЈЕЛЕТИћ, 1990, БЈеЛЕтИћ, 2012]; Лома, 1999: 133-136, 140; РСАНУ V, 1968: 97 (Бипанаи), 98 (Ђипати), 99 (Ђипоња, Ђипоша), 119 (Ђупкоша), XI, 1981: 63 (ку̀рало), 75 (кі̀р-ић), XVII, 2006: 290 (ожети); Бјелетић, 2012: 7, 8; ЕРСЈ 1, 2003: 226; Лома, 2013: 123, 124; уп. Луис-Шорт, 1891: 278 (canesco); Бјелетић, 2011: 200; ЕРХСЈ 1, 1971: 244; уп. Михајловић, 2002: 651, 652; Һорић, 1982: 142, 143; уп. Клајн, 2002 II: 89; Бјелетић, 1995: 206; уп. Бјелетић, 2001: 112, 113; Митровић, 1985: 182; етим. Ж. В.). Сетимо се, у овоме духу, како и Цезарови војници-легионари певају током Цезарова галског тријумфа у Риму своме заповеднику најјавније следећу песму, јер и ван Рима је он радо обљубљивао удате жене:

„Građani, bdijte nad ženama: 'ćelavi preljubnik ${ }^{20}$ vozi se.



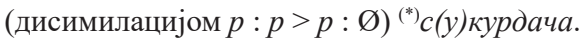

${ }^{17}$ Уп. горе курејбало од курёбало.

${ }^{18}$ То онда значи да овденаведени називи „новијег датума” и постања не могу бити старији од ијекавског рефлекса јата и преласка рjӗ > ре , као и (османских) турцизама.

${ }_{19}$ Реч би била о развоју: *бело орало, ген. *белог орала > (срастањем) *белорало, ген. *белорала $>$ (синкопом - $a$ - у ген.) *белорало, ген. *белорла > (начинивши из ген. нови ном.) *белорао, ген. *белорла > (декомпозицијом) бели орао, ген. белог орла.

${ }^{20}$ У Прегледу римске књижевности дат је превод ћелав(u) заводник, а наводи се и пример како су војници-легионари цара Аурелијана певали током тријумфа најјавније чак и о рекама војничке, али и невине крви које је свако од њих проли(ва)о:
}

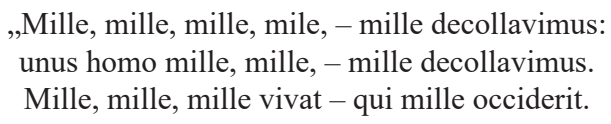


Zlato u Galiji spisk[ô] si što si ga ovdje posudio"

(Светоније Транквил, 1978: 40).

Како год да било, и да јесте било, да сумирамо како је у случају горенаведених српских презимена реч о славизираним Романима, те да то није ништа необично јер су наши приморски и копнени Романи у највећем омеру природно били посрбљени или похрваћени, зависно од језика, односно народа на чијој су средњовековној језичко-етничкој територији и живели. На тај начин, горенаведени Палавестре/Палавастре/Палавестрићи, Палонге/Палонгићи, (?) Паладруићи/Паладрићи, (?) Палокути, (?) Палаврти / (?) Палавртићи / (?) Палаврте / Паловртићи, (?) Палаорићи/Палавре, (?) Паламури и (?) Палдеде јесу, етнички, посрбљени Романи са српскога приморја и копна. Додајемо и то да су неки од ових наведених сигурно испрва били или и данас јесу католици, односно, етнички, Срби католици ${ }^{21}$ (в. Вељковић, 2020: 214).

\section{Литература}

Антонијевић, 2008: Ž. Antonijević, S frulom nisam prolazio kod devojaka (Ispovest za „Blic nedelje”: virtuoz na fruli Bora Dugić). Blic, 11. 5. 2008.

Баженова, 2002: А. Баженова, Словарь исторических родокоренных имен и прозваний Славян и Русов за два тысячелетия (ISBN 5-88109-15-3).

Белић, 1976: А. Белић, Фонетика. Београд: Научна књига.

Бјелетић, 1990: М. Бјелетић, Родбинска терминологија код Срба у Румунији, у: Научни састанак слависта у Вукове дане, 20/2. Београд - Панчево - Нови Сад - Тршић: МСЦ, 391-402.

Бјелетић, 1994: М. Бјелетић, Терминологија крвног сродства у српскохрватском језику. Јужнословенски филолог, L (50), 199-208.

Бјелетић, 1995: М. Bjeletić, Turcizmi u srpskohrvatskoj terminologiji srodstva. Južnoslovenski filolog, LI (51), 203-222.

Бјелетић, 2001: М. Бјелетић, Беле пчеле, у: Кодови словенских култура: боје. Београд: Издавачко предузеће, 106-119, 163.

$$
\begin{gathered}
\text { Tantum vini nemo habet - quantum fudit sanguinis.” } \\
\text { „Хиљаде и хиљаде њих - главе смо им преклали: } \\
\text { Сваки одд нас хиљаде њих - главе смо им преклали! } \\
\text { Хиљаде пута жив био ко хиљаду закоље! } \\
\text { Вина крчмар нема кол’ко - крви војник искоље! }
\end{gathered}
$$

(Будимир-Флашар, 1991: 103; превод Ж. В.).

${ }^{21}$ Да су, етнички, Срби католици и дан-данас једна жива категорија, и уосталом ништа необично јер вера није вододелница народа, в. Вељковић, 2018: 281, 282. 
Бјелетић, 2011: М. Бјелетић, Допринос проучавању родбинске терминологије у српском језику(чукундед), у: Современная славистика и научное наследие С.Б. Бернштейна. Москва: РАН, 199-202.

Бјелетић, 2012: М. Белетич, Дополнение к исследованию терминологии родства в сербском языке (чукундед), у: Этимология 2009-2011. Москва: РАН, 3-18.

Брачолини, 1962: P. Braćolini, Liber facetiarum. Knjiga šala. Sarajevo: Veselin Masleša.

Будимир-Флашар, 1991: М. Будимир, М. Флашар, Преглед римске књижевности. Београд: Научна књига.

Вељковић, 2013: Ж. Б. Вељковић, Порфирогенитова „Лонтодокла“ - данашњи Љутотук - неколики балканоромански топоними Бјелопавлићког краја. Октоих, III/4 (2013), 13-26.

Вељковић, 2018: Ж. Б. Вељковић, Још једном о натпису попа T’b'ходрага из Лиштана̂ код Ливна [осврт на чланак Marić i dr., „Pop Tjehodrag i njegov natpis“, Povijesni prilozi 33, 2007, 9-32]. Теолошки погледи, LI (2/2018), 275-317.

Вељковић, 2020: Ж. Б. Вељковић, Marica Čunčić, Marta Perkić, Hrvatski glagoljski natpis Župe dubrovačke iz 11. stoljeća (Slovo 59, Zagreb, 2009, 77-122) (научна критика). Српска баштина, V/1 (2020), 210-216.

Грејма-Кин, 2001: А. J. Greimas, T. М. Keane, Dictionnaire du moyen français. Paris: Larousse-Bordas/HER.

Грковић, 1977: М. Грковић, Речник личних имена код Срба. Београд: Вук Караџић.

Дедијер, 2004: J. Дедијер, Хериеговина (репринт). Гацко: Друштво за очување баштине / ДОБ.

Драшковић, 1987: V. Drašković, Pesma o Rolandu. Beograd: Narodna knjiga.

Драшковић, 1994: V. Drašković, Uporedna gramatika romanskih jezika. Sremski Karlovci - Novi Sad: IK Z. Stojanovića.

ЕРСЈ 1-, 2003-: Етимолошки речник српског језика 1-. Београд: САНУ.

EPXCJ 1-3, 1971-1973: P. Skok, Etimologijski rječnik hrvatskoga ili srpskoga jezika 1-3. Zagreb: JAZU.

Иванић 1911: И. Иванић, Шта је Маћедонија?, у: Велики илустровани календар „Уједињено српство” за 1911. годину, Chicago (Чикаго): Штампарија „Уједињеног српства”, 79-94.

Ивековић-Броз PXJ, 1901: I. Broz, F. Iveković, Rječnik hrvatskoga jezika I-II. Zagreb: Štamparija Karla Albrechta.

Информатор 1: Михаило Димитријевић, *1926, Београд (1986. г.; пореклом из Шенђурца/Сентђурђа/Санђурђа и Темишвара).

Јалап-Ђинђић, 2016: Н. Yalap, M. Đinđić, Çağdaş Sırp edebiyat dilinde arkaik Türkçe kelimeler ve bu kelimelerin çağdaş Türk edebiyat dilindeki durumu, y: III Beynalxalq Türk dünyası araşdırmaları simpoziumunun 25-27 May 2016, Baki. Materialları, 275-278.

Клаић, 1966: В. Klaić, Veliki rječnik stranih riječi, izraza i kratica. Zagreb: Zora. 
Клајн, 2002 I-II: И. Клајн, Творба речи у савременом српском језику I-II. Београд: Одбор за стандардизацију српског језика.

Лома, 1993/95: А. Лома, Језичка прошлост југоисточне Србије у светлу топономастике, у: Зборник реферата са научног скупа „Говори призренскотимочке области и суседних дијалеката “. Ниш, 107-137.

Лома, 1999: А. Лома, „Петлић”, „палидрвце” или „оплодитељ”?, у: Кодови словенских култура: делови тела, 4. Београд: Издавачко предузеће, 131-145.

Лома, 2005: А. Лома, Глаголи *koriti и *kuditi у словенској и српској ономастици. Ономатолошки прилози, XVIII. Београд: САНУ, 21-31.

Лома, 2013: А. Лома, Топонимија Бањске хрисовуље. Београд: САНУ.

Луис-Шорт, 1891: С. T. Lewis, C. Short, A Latin dictionary. Oxford: Clarendon press.

Милићевић, 2005: R. Milićević, Hercegovačka prezimena. Beograd: Svet knjige.

Миљанићи, 2002: В., А. Миљанић, Презимена у Црној Гори. Београд - Нови Сад: Београдска књига, В. Миљанић.

Митровић, 1985: Ј. Д. Митровић, Називи за степене потомака и предака код Срба. Гласник Етнографског музеја у Београду, 49, 181-183.

Михајловић, 2002: В. Михајловић, Српски презименик. Нови Сад: Аурора.

Морошкин 1867: М. Морошкинъ, Славянскій именословъ. Санктпетербургъ: Е. И. В. Канцелярія.

Покорни, 2007: J. Pokorny, Proto-Indo-European etymological dictionary. Moscow: Indo-European language revival association.

PJA3У I-XXIII, 1880-1976: Rječnik hrvatskoga ili srpskoga jezika I-XXIII. Zagreb: JAZU.

PMC-MX 1-6, 1967-1976: Речник српскохрватскога књижевног језика 1-6. Београд - Загреб: МС (1-6), MX (1-3).

РСАНУ I-, 1959-: Речник српскохрватског књижевног и народног језика I-. Београд: САНУ.

Светоније Транквил, 1978: G. Svetonije Trankvil, Dvanaest rimskih careva. Zagreb: Naprijed.

Софоклис, 1900: E. A. Sophocles, Greek lexicon of the Roman and Byzantine periods. New York: Ch. Scribner's sons.

Станић, 1994: Р. Станић, Стари српски надгробни споменици у Мостару. Епитафи надгробника на Пашиновачком гробљу. Саопштеља, XXVI (26), 161-181.

Ћорић, 1982: Б. Ћорић, Моциони суфикси у српскохрватском језику. Београд: Филолошки факултет.

Шкаљић, 1989: A. Škaljić, Turcizmi u srpskohrvatskom jeziku. Sarajevo: Svjetlost.

Шуљгач, 2016: В. П. Шульгач, Нариси з праслов'янської антропонімї III. Киів: НАНУ.

Žarko B. Veljković 


\title{
ON THE SURNAME PALAVESTRA AND SIMILAR SURNAMES
}

\begin{abstract}
Summary
In this article, the etymology of the Serbian surname Palavestra and similar Serbian surnames (e. g. Palonga, Palovrtić) has been scrutinized. Their first part, Pala-/Palo-, has been etymologized from Dalmatian Romance (and - maybe from there - Balkan Romance as well) word *pala/*pal-o- "sword". Also, the partial possibility of obscene meaning of this word in some of the surnames mentioned has been scrutinized, in addition to what the etymological suggestions of few Serbian terms for distant male ancestors has been given: parđipan, (?) *kurđup, kurlebalo, kurcula, sukurebalo, sukurdov with feminine form sukurdača, (?) *surdepač, *ožmikur, kurajber, maybe even beli orao.
\end{abstract}

Key words: Palavestra, parđipan, (?) *kurđup, kurlebalo, kurcula, sukurebalo, sukurdov, (?) *surdepač, *ožmikur, kurajber, beli orao. 